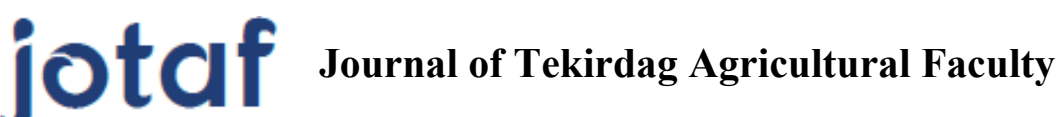

Eylül/September 2020, 17(3)

Başvuru/Received: 11/03/20

Kabul/Accepted: 10/07/20

Tekirdağ Ziraat Fakültesi Dergisi

\section{Determination of Nutritional Status of Olive (Olea europaea L.) Trees Grown in Izmir and Mugla Province in Terms of Boron and The Other Microelements with Soil and Leaf Analyzes}

İzmir ve Muğla İllerinde Yetiştirilen Zeytin (Olea europaea L.) Ağaçlarının Bor ve Mikro Elementler Yönünden Beslenme Durumunun Yaprak ve Toprak Analizleri ile Belirlenmesi

\author{
Aise DELIBORAN ${ }^{1}$, Kerem SAVRAN ${ }^{2}$, Ozgur DURSUN ${ }^{3}$, Onder ERALP ${ }^{4}$, Tulin PEKCAN ${ }^{5}$, \\ Hatice Sevim TURAN ${ }^{6}$, Erol AYDOGDU ${ }^{7}$, Idris CILGIN ${ }^{8}$, Handan ATAOL OLMEZ ${ }^{9}$, Sule \\ SAVRAN ${ }^{10}$, Abdullah Suat NACAR ${ }^{11}$
}

\begin{abstract}
This study was conducted to determine the nutritional status of olive cultivated land and olive plant in Izmir and Mugla province in terms of boron and other elements. For this purpose, 254 soil samples $(0-30 \mathrm{~cm}$ depth) and 254 leaf samples were taken simultaneously with GPS coordinates from the olive production areas and analyzed (125 gardens in Datca, Koycegiz, Milas, Ula, Seydikemer districts of Mugla province / 129 gardens in Aliaga, Bayindir, Bergama, Dikili, Foca, Karaburun, Kemalpasa, Menderes, Menemen, Odemiş, Seferihisar, Selcuk, Tire, Torbali and Urla district of Izmir province). In the soil samples texture, pH, EC, lime, organic matter, extractable boron, iron, copper, zinc and manganese analysis were done. In the leaf samples total boron, iron, copper, zinc and manganese content were determined. According to the analysis results, the nutritional studies of olive were determined in term of boron and other elements. According to the results of the research, boron contents of the research areas soils ranged between 0.20 and $5.24 \mathrm{mg} \mathrm{kg}^{-1}$ and the average level was determined as $1.21 \mathrm{mg} \mathrm{kg}^{-1}$. In the boron content distribution of the soils in the research area $13.78 \%$ is low, $76.38 \%$ is sufficient, $9.45 \%$ is more and $0.39 \%$ is too high. Boron contents of olive leaves ranged between 8.66 and $29.33 \mathrm{mg} \mathrm{kg}^{-1}$ and the average level was determined as $8.66 \mathrm{mg} \mathrm{kg}^{-1}$. In the boron content distribution of the leaves in the research area $85.04 \%$ is low, $14.96 \%$ is sufficient. Based on the B contents of all soil and leaf samples it was interesting to note that TSOrumlu Yazar/Corresponding Author: Aise Deliboran, Olive Research Institute, University Street No:43 35100, Izmir, Turkey. E-mail: aisedeliboran@gmail.com (iD) OrcID:0000-0002-0816-9535

${ }^{2}$ Kerem Savran, Olive Research Institute, University Street No:43 35100, Izmir, Turkey. E-mail: muzafferkerem.savran@tarimorman.gov.tr@ OrcID: 0000-00029048-4947.

${ }^{3}$ Ozgur Dursun, Olive Research Institute, University Street No:43 35100, Izmir, Turkey. E-mail: ozgurdursun47@gmail.com (iD) OrcID: 0000-0001-6849-3946.

${ }^{4}$ Onder Eralp, Olive Research Institute, University Street No:43 35100, Izmir, Turkey. E-mail: ondereralp@hotmail.com (D) OrcID: 0000-0002-3155-2022.

${ }^{5}$ Tulin Pekcan, Olive Research Institute, University Street No:43 35100, Izmir, Turkey. E-mail: tulhan35@hotmail.com (iD OrcID: 0000-0002-5534-2548.

${ }^{6}$ Hatice Sevim Turan, Olive Research Institute, University Street No:43 35100, Izmir, Turkey. E-mail: haticesevim.turan@tarim.gov.tr (iD) OrcID: 0000-00034266-7420.

${ }^{7}$ Erol Aydogdu, Olive Research Institute, University Street No:43 35100, Izmir, Turkey. E-mail: erolaydogdu65@hotmail.com (DD OrcID: 0000-0001-8682-4227. ${ }^{8}$ Idris Cilgin, Olive Research Institute, University Street No:43 35100, Izmir, Turkey. E-mail: idriscilgin@tarimorman.gov.tr (iD OrcID: 0000-0002-3080-4371. ${ }^{9}$ Handan Ataol Olmez, Olive Research Institute, University Street No:43 35100, Izmir, Turkey. E-mail: olmezata@hotmail.com (DD OrcID: 0000-0003-4577-8804. ${ }^{10}$ Sule Savran, Olive Research Institute, University Street No:43 35100, Izmir, Turkey. E-mail: sulematyar@gmail.com (DD OrcID: 0000-0001-6105-2407.

${ }^{11}$ Abdullah Suat Nacar, GAP Agricultural Research Institute, Recep Tayyip Erdogan Bulvari N:106 PK:75 63040 Sanliurfa, Turkey. E-mail: abdullahsuat.nacar@tarimorman.gov.tr(iD) OrcID: 0000-0002-8372-7381.
\end{abstract}

Atıf/Citation: Deliboran, A., Savran, K., Dursun, O., Eralp, O., Pekcan, T., Turan, H. S., Aydogdu, E., Cilgın, I., Ataol Olmez, H., Savran, S., Nacar, A. S.. Determination of Nutritional Status of Olive (Olea Europaea L.) Trees Grown in Izmir and Mugla Province in Terms of Boron and The Other Microelements with Soil and Leaf Analyzes Tekirdă̆ Ziraat Fakültesi Dergisi, 17 (3), 392-405. 
although $85.83 \%$ of the soils have sufficient boron, $85.04 \%$ of the leaves show boron deficiency, indicating that boron nutritional problems are experienced. Also according to the results of analysis, it was determined that there were no nutritional problems in terms of iron, and that there were serious nutritional problems in terms of boron and zinc. It was determined that nutritional problems in term of manganese and copper slightly. As with all plant species, fertilization programs for olive plant should be established according to soil and leaf analysis result. According to the results of analysis, it is important to give the deficient macro and micronutrients in addition to phosphorus, nitrogen and potassium fertilizers which will be given with basic fertilization.

Keywords: Boron, Plant nutrition, Olive production, Mineral status

\section{Özet}

$\mathrm{Bu}$ çalışma, İzmir ve Muğla ilerinde zeytin yetiştiriciliği yapılan toprakların ve zeytin bitkisinin bor ve diğer elementler yönünden beslenme durumunun belirlenmesi amaciyla yürütülmüştür. Bu amaçla 254 adet toprak (0$30 \mathrm{~cm}$ ) ve yaprak örneği GPS koordinatlı olarak eş zamanlı alınmış ve analiz edilmiştir (Muğla ilinde: 125 bahçe Datca, Köyceğiz, Milas, Ula, Seydikemer/İzmir ilinde: 129 bahçe Aliağa, Bayındır, Bergama, Dikili, Foça, Karaburun, Kemalpaşa, Menderes, Menemen, Ödemiş, Seferihisar, Selçuk, Tire, Torbalı, Urla). Toprak örneklerinde; tekstür, $\mathrm{pH}, \mathrm{EC}$, kireç, organik madde, ekstrakte edilebilir $\mathrm{B}, \mathrm{Fe}, \mathrm{Cu}, \mathrm{Zn}, \mathrm{Mn}$; yaprak örneklerinde ise toplam $\mathrm{B}, \mathrm{Fe}, \mathrm{Zn}, \mathrm{Mn}, \mathrm{Cu}$ analizleri yapılmıştır. Araştırma sonuçlarına göre, toprakların bor içerikleri 0.20 ve $5.24 \mathrm{mg} \mathrm{kg}^{-1}$ arasında değişmiş, ortalama bor içeriği ise $1.21 \mathrm{mg} \mathrm{kg}^{-1}$ olarak belirlenmiş̧tir. Araştırma alanı toprakları ekstrakte edilebilir B içerikleri bakımından incelendiğinde $\% 13.78$ 'i az, \%76.38'i yeterli, \%9.45'i fazla ve \%0.39'u çok fazla sınıfında yer almıştır. Yaprakların bor içerikleri 8.66 ve $29.33 \mathrm{mg} \mathrm{kg}^{-1}$ arasında değişmiş, ortalama bor içeriği ise $8.66 \mathrm{mg} \mathrm{kg}^{-1}$ olarak belirlenmiştir. Araştırıma alanı yaprakların bor içerikleri dağı̆lımı ise \%85.04'ü az, \%14.96's1 yeterli olarak belirlenmiştir. Toprak ve yaprakların bor içerikleri birlikte değerlendirildiğinde toprakların \%85.83'nün yeterli bor içermesine rağmen yaprakların \%85.04'nün yetersiz bor içermesi ciddi bor beslenme sorunlarının yaşandığını göstermektedir. Analiz sonuçlarına göre, demir bakımından beslenme sorunlarının olmadığı, çinko bakımından ciddi, mangan ve bakır bakımından ise azda olsa beslenme sorunlarının yaşandığı görülmektedir. Tüm bitki türlerinde olduğu gibi zeytin bitkisi için gübreleme programları toprak ve yaprak analiz sonuçlarına göre oluşturulmalıdır. Analiz sonuçlarına göre, temel gübreleme ile verilecek fosfor, azot ve potasyum gübrelerine ek olarak mikro besin maddelerinin verilmesi önemlidir.

Anahtar Kelimeler: Bor, Bitki besleme, Zeytin üretimi, Mineral durumu 


\section{Introduction} and leaf analyzes

Hatay-Maras-Mardin strip is known that native country of olive (Olea europaea L.). Olive has wide production areas on the Aegean and Mediterranean coasts and this reason, it carries a distinct economic importance for Turkey and Mediterranean basin countries. Demand of olives increases considerably because of the fruit processed in different ways and the positive effects of oil on human nutrition (Deliboran et al., 2019; 2019a).

According to 2013 data, World crude olive production is 20.3 millions tons in 10.2 million ha area. Spain is the leading country with 7.9 millions tons of production and Italy, Greece and Turkey are followed the Spain with 2.9; 2.0 and 1.7 million ton olive production, respectively (Deliboran et al., 2019).

Olive are generally grown by conventional methods in the Marmara, Aegean, Mediterranean, Southeastern Anatolia and the Black Sea Region of Turkey. There are about 169 million olive trees in Turkey, and 17\% of the new plant has not yet reached the yield situation in the garden. Considering the presence of trees, the Aegean Region takes the first place with 83.030.213 trees, followed by the Mediterranean (40.418.083), Marmara (29.754.049), Southeast Anatolia Region (15.254.670) and the Black Sea Region, respectively (Deliboran et al., 2019). The region where olive production is most intense (75\%) is being cultivated in many different topography, soil groups and microclimate fields in Canakkale, Balikesir, Izmir, Manisa, Aydin and Mugla in the Aegean Region. There are 24.138.088 table varieties in 997.871 da area, and 58.892.125 oil varieties in 3.417.017 da area, and most of the production is made with oil varieties (Anonymous, 2014).

Based on the presence of trees, it is understood that Mugla and Izmir province $44 \%$ of the olive tree presence in the Aegean Region. It has been observed that causes of low yield in the Aegean Region are periodicity, climate events and cultural practise mistakes. On the other hand, it is determined in the research that fertilization is done well and scientific principles are not followed. As a result, average yield of oil varieties decreased to $11 \mathrm{~kg}^{\mathrm{g}}$ tree ${ }^{-1}$. The aim of the olive farmer should be to increase the yield and quality of olive and to reduce production fluctuations arising from periodicity (Anonymous, 2011); (Deliboran et al., 2019; 2019a); (Doran and Aydın, 1999).

In recent years, as the reason for the increase of olive production in Turkey can be listed that i) improvement of climate conditions, ii) planting of new olive sapling, iii) studies on encouraging olive production. Progress in parallel with positive developments of olive production; these are i) modernization of olive extraction facilities, ii) increased capacity, iii) because of this reason, increase of olive oil quantity and quality (Deliboran et al., 2019; 2019a; 2019b). According to Olive Oil Sector Report (2013); while the average olive oil production was 61 thousand tons before the 1995/96 season, it doubled in the following twelve seasons (1996/1997-2007/2008) to an average of 120 thousand tons. Olive plants which are very important for Turkey's economy, it is more important for the province of farmers and the economy will be carried out the research. In this respect, the studies to be carried out in the region and increasing the yield and especially the quality (nutritional value) of olives will make a major contribution to the national and regional economy.

Especially the trend of the world olive oil consumption in recent years is that the olive oil is produced under high quality and controlled conditions as much as possible. Olive oil producers will need to turn to high quality and qualified olive oil production in order to maintain their current market shares and enter new markets. In the world trade, the importance of olive oil is expected to increase due to the increasing awareness of health and the demand to food produced by controlled means. Increased income and rising living standards will lead to new markets for olive oil. Indeed, world olive oil consumption was 30.611 million tons, consumption of Turkey was 147.800 tonnes, per capitata consumption was $2 \mathrm{~kg}$ in 2014 (Anonymous, 2014). Turkey is among the net oilexporting countries. The highest amount of olive oil exports was 931 tons and 291 million dollars in 2004/05 season. The increase in the demand for olive oil in the world have contributed to the emergence of new export markets for Turkey. In 2012, olive oil was exported to 101 countries. The highest olive oil export was realized to USA with 17 million dollars by years 2012, This was followed by Saudi Arabia with \$ 13 million and Japan with $\$ 7.3$ million. Exports to these three countries was accounted for $45 \%$ of Turkey total exports (Olive Oil Sector Report, 2013). Olive/olive oil production and export is important contribution to the national economy with its place in export. About 400.000 families earn a livelihood from olive farming in Turkey. 
Even with the current production amount, the contribution of olive and olive oil to the national economy is not underestimated. However, Turkey is behind some countries in term of quality and exports because of the product obtained from unit area. This is an indication that olive and olive oil production has not reached the desired level yet (Deliboran et al., 2019a). The most appropriate solution to increase agricultural production is to increase the amount of product taken from the unit area. This can only be achieved by balanced fertilization. For this reason, the existing nutritional problems of the production areas should be identified well.

In recent studies, it has been revealed that nutritional problems related to micronutrients are common in the soil of the region. In the survey studies done to determine their nutritional status of Turkey olive groves, it was determined that most deficiency of boron $(\mathrm{B})$, zinc $(\mathrm{Zn})$, potassium $(\mathrm{K})$ and nitrogen $(\mathrm{N})$, respectively (Dikmelik, 1989); (Aksalman et al., 1993); (Doran and Aydin, 1999); Deliboran et al., 2019; 2019a, 2019b). Although micronutrients are taken in small amounts by plants, they have important functions in plant metabolism. B, which is one of the micronutrients. $\mathrm{B}$ is one of the absolute micronutrients necessary for plants and its deficiency and toxicity simptoms are common. For this reason, the role of B in plant nutrition is gain a very careful position (Deliboran et al., 2019a).

As a result, increasing olive/olive oil yield and quality is importance for the regional farmer and ultimately for the country's economy. This will only be possible with the determination of the nutritional problems of the existing production areas and fertilization studies according to the results to be obtained. With this study, it was aimed to examine the boron nutritional status of olive groves in Izmir and Mugla province with soil-leaf analysis, to compare the obtained results with reference values and to identify the problems that arise due to various reasons.

\section{Materials and Methods}

\subsection{Research area}

The fields of olive growing in Izmir and Mugla province constitute the material of the study. In November and December 2015, soil and plant samples were taken simultaneously from 254 different olive groves to represent the region. The number of soil and plant samples and production areas are given in Table 1.

Table 1. The number and distribution of sample

\begin{tabular}{|c|c|c|c|c|c|}
\hline \multicolumn{2}{|c|}{ Countries } & \multirow{2}{*}{$\begin{array}{c}\text { Soil } \\
\text { Samples } \\
\text { (piece) } \\
\end{array}$} & \multirow{2}{*}{$\begin{array}{c}\begin{array}{c}\text { Distribution of } \\
\text { Soil Samples }\end{array} \\
(\%)\end{array}$} & \multirow{2}{*}{$\begin{array}{c}\text { Leaf Samples } \\
\text { (piece) }\end{array}$} & \multirow{2}{*}{$\begin{array}{c}\begin{array}{c}\text { Distribution of } \\
\text { Leaf Samples }\end{array} \\
(\%) \\
\end{array}$} \\
\hline \multirow{6}{*}{ Mugla } & & & & & \\
\hline & Datca & 2 & 1.60 & 2 & 1.60 \\
\hline & Koycegiz & 4 & 3.20 & 4 & 3.20 \\
\hline & Milas & 80 & 64.00 & 80 & 64.00 \\
\hline & Ula & 9 & 7.20 & 9 & 7.20 \\
\hline & Seydikemer & 30 & 24.00 & 30 & 24.00 \\
\hline \multirow{10}{*}{ Izmir } & Aliaga & 9 & 6.98 & 9 & 6.98 \\
\hline & Bayindir & 23 & 17.83 & 23 & 17.83 \\
\hline & Bergama & 12 & 9.30 & 12 & 9.30 \\
\hline & Dikili & 8 & 6.20 & 8 & 6.20 \\
\hline & Foca & 2 & 1.55 & 2 & 1.55 \\
\hline & Karaburun & 4 & 3.10 & 4 & 3.10 \\
\hline & Kemalpasa & 10 & 7.75 & 10 & 7.75 \\
\hline & Menderes & 9 & 6.98 & 9 & 6.98 \\
\hline & Menemen & 3 & 2.33 & 3 & 2.33 \\
\hline & Odemis & 8 & 6.20 & 8 & 6.20 \\
\hline
\end{tabular}


Deliboran \& Savran \& Dursun \& Eralp \& Pekcan \& Turan \& Aydoğdu \& Çllgin \& Ölmez \& Savran \& Nacar Determination of nutritional status of olive (Olea Europaea L.) trees grown in Izmir and Mugla province in terms of boron and the other microelements with soil

\begin{tabular}{lcccc} 
and leaf analyze \\
\hline Seferihisar & 7 & 5.43 & 7 & 5.43 \\
Selcuk & 10 & 7.75 & 10 & 7.75 \\
Tire & 5 & 3.88 & 5 & 3.88 \\
Torbali & 12 & 9.30 & 12 & 9.30 \\
Urla & 7 & 5.42 & 7 & 5.42 \\
\hline Total & 254 & 100.00 & 254 & 100.00 \\
\hline
\end{tabular}

\subsection{Sampling method, selection of sampling sites and taking soil samples}

In November-December, the leaf samples were plucked from the one-year branches coming from the middle part of the tree crown with stems including a total 50 piece. The leaf sample were taken different trees to represent the garden from 4 different sides of the trees, namely East, South, West and North. Soil samples were taken simultaneously from 0-30 cm depth. Sampling was carried out in GPS coordinates.

\subsection{Preparation of samples for laboratory analysis}

Soil samples brought to the laboratory, stone and plant particles were extracted and spread on clean packaging paper and allowed to air dry. The dried soils were forged with wooden mallets, passed through a $2 \mathrm{~mm}$ steel sieve, put into glass jars, labeled and made ready for analysis. Leaf samples brought to the laboratory were first washed with tap water, then with $0.1 \mathrm{~N} \mathrm{HCl}$ and deionized water 2 times, then the excess water was taken with drying paper and dried in air circulation drying cabinet at $70^{\circ} \mathrm{C}$ for 48 hours (until constant weight) and milled in tungsten coated mill prepared for analysis.

\subsection{Soil analyzes}

Texture (sand, silt and clay fractions of soil samples) were determined by hydrometer method, according to Tuzuner (1990). Soil reaction $(\mathrm{pH})$ was determined by $\mathrm{pH}$ meter from 1: 2.5 ratio of soil + pure water mixture, according to Tuzuner (1990). Electrical conductivity (ECx106 $\mu$ mhos $\mathrm{cm}^{-1}$ ) was measured using electrical permeability instrument from 1:5 ratio of soil: pure water mixture, according to Tuzuner (1990). Lime $\left(\mathrm{CaCO}_{3} \%\right)$ was determined as volumetric by Scheibler calcimetry, according to Tuzuner (1990). Organic matter (OM) (\%) was determined by Walkey-Black method according to Tuzuner (1990). Available calcium (Ca), magnesium (Mg), sodium $(\mathrm{Na})$, potassium $(\mathrm{K})$ were determined by ICP-OES (Varian-Vista) from extracted with $1 \mathrm{~N}$ ammonium acetate (pH 7.0) as reported by Tuzuner (1990). Available phosphorus (P) was determined by Olsen (1972)'s $\mathrm{NaHCO}_{3}$ method (Kacar, 1982). Available iron (Fe), Zn, manganese (Mn) and copper $(\mathrm{Cu})$ were determined by ICP-OES (Varian-Vista) after extraction with $0.005 \mathrm{M} \mathrm{DTPA}+0.01 \mathrm{M} \mathrm{CaCl}_{2}+0.1 \mathrm{M}$ TEA (pH 7.3) according to Lindsay and Norvell (1978) (Kacar, 1982). Available B was determined by the hot water extraction method according to Gupta (1967), and Gestring and Soltanpour (1981).

\subsection{Plant analysis}

After the samples are brought to the laboratory, the samples were washed with first the tap water, $0.1 \mathrm{~N} \mathrm{HCl}$ and 2 times deionized water, respectively. Then the excess water is taken with drying paper. The samples were made ready for analysis by drying in air circulating cabinet at $70^{\circ} \mathrm{C}$ for 48 hours (until constant weight) and grinded

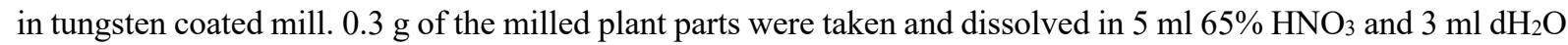
in a closed system microwave device (Cem Mars Xpress), the final volumes were completed to $25 \mathrm{ml}$ with ultra deionized water and filtered through blue band filter paper. The concentration of $\mathrm{B}$ and other nutrients in filtrates was determined by ICP-OES (Varian, Vista). Measurements of mineral concentrations were checked with certified values of the relevant minerals in the reference plant materials obtained from the National Institute of Standards and Technology (NIST, Gaithersburg, MD, USA). 


\section{Results and Discussion}

\subsection{Some physical and chemical properties of soils}

\subsubsection{Texture}

Sand, clay, silt content of the soils are ranged between $19.52-83.68 \%, 0-58.88 \% ; 2.72-65.76 \%$ respectively (Table 2). According to Anonymus (1951) $39.76 \%$ of the soil is sandy loamy (SL), $14.96 \%$ is loamy (L), $17.72 \%$ is clayey loamy (CL), $15.75 \%$ is sandy clayed loam (SCL), $9.06 \%$ is clayed (C) and 2.36\% is sandy clayed (SC) (Table 4). Olive shows better development in well-ventilated, low ground water, L, CL, SL soils (Kacar and Katkat, 1999), generally in lightly structured soils (34-65\% sand, 24-28\% clay) (Ozbek, 1981); (Mengel and Kirkby, 1987). Considering that the differently structured soils from sandy to clay are suitable for olive cultivation (Colakoglu, 1985) and considering the texture classes in the study as a whole, it is understood that most of them are light bodied and suitable for olive farming. In some studies conducted to determine the nutritional status of olives, it has been determined that soil is clayloam in the province of Izmir (Aydogdu, 2011); loam and clay-loam in Gemlik region (Uysal et al., 2011), clay-loam, loam and sand in Armutlu peninsula (Uysal et al., 2016); loam and clay-loam on the Kapidag Peninsula (Saglam et al., 2008); loamy and clayey loam structure in the Derik region (Doran et al., 2008).

Table 2. The lowest, highest and average values of structure, pH, EC, lime and organic matter of soil samples

\begin{tabular}{|c|c|c|c|c|c|c|c|}
\hline \multirow{3}{*}{ Values } & \multicolumn{3}{|c|}{ Structer } & \multirow{3}{*}{ pH } & \multirow{3}{*}{$\frac{\mathrm{EC}}{\left(\mathrm{dS} \mathrm{m}^{-1}\right)}$} & \multirow{2}{*}{\multicolumn{2}{|c|}{ OM }} \\
\hline & Sand & Clay & Silt & & & & \\
\hline & \multicolumn{3}{|c|}{$(\%)$} & & & \multicolumn{2}{|c|}{$(\%)$} \\
\hline Lowest & 19.52 & 0.00 & 2.72 & 5.12 & 0.05 & 1.16 & 0.86 \\
\hline Highest & 83.68 & 58.88 & 65.76 & 8.36 & 1.16 & 74.50 & 5.74 \\
\hline Average & 52.26 & 23.14 & 24.44 & 7.14 & 0.35 & 14.50 & 2.24 \\
\hline Basıklık & -0.94354 & -0.55736 & 1.329273 & 0.017368 & 0.621149 & 2.203631 & 1.802974 \\
\hline Çarpıklık & -0.07611 & 0.339876 & 0.666836 & -1.06018 & 0.950915 & 1.816453 & 1.118681 \\
\hline Ortanca & 52.4 & 20.32 & 22.72 & 7.465 & 0.3 & 4.12 & 2.11 \\
\hline Stds & 14.32469 & 11.3997 & 9.112166 & 0.7307 & 0.204119 & 19.98332 & 0.807014 \\
\hline Varyans & 205.1968 & 129.9531 & 83.03157 & 0.533923 & 0.041665 & 399.3332 & 0.651271 \\
\hline $\mathrm{DK}$ & 27.40962 & 49.25636 & 37.28309 & 10.22465 & 58.14964 & 137.7925 & 36.0141 \\
\hline
\end{tabular}

\subsection{2. $\mathrm{pH}$}

The $\mathrm{pH}$ of the soils ranged from 5.12 to 8.36 (Table 2). Within the total area, $50.39 \%$ of the soil is mild alkaline, $22.83 \%$ is neutral, $22.44 \%$ is med acid, $3.94 \%$ is alkaline (Table 4). Olive tree can be grown in a wide soil reaction (Ozbek, 1981); (Llamas, 1984); (Hartmann and Lilleland, 1966). Considering that it develops well in slightly acidic (pH 6.5) and slightly alkaline (pH 7.8) soils, and 50.39\% of the research area soils are slightly alkaline and $22.83 \%$ are neutral, it is understood that the soils of the region is suitable for olive farming in this respect. In order to reduce the $\mathrm{pH}$ in the alkaline reaction soils (1.55\%), powder sulfur should be applied in the fall, preferably with farm manure or physiological acid fertilizers should be used. In some studies conducted to determine the nutritional status of olives, soils are determined that neutral and medium alkaline in the Western Anatolian Region; a neutral and slightly alkaline in the Gemlik region (Uysal et al., 2011), acid in the Armutlu peninsula (Uysal et al., 2016); light and medium acid in Kapidag peninsula (Saglam et al., 2008); slightly alkaline in the Izmir (Aydogdu, 2011), Derik (Doran et al., 2008) and Urfa region (Soylemez et al., 2017).

Table 3. The lowest, highest and average value of extractable $\mathrm{B}, \mathrm{Fe}, \mathrm{Zn}, \mathrm{Cu}$ and $\mathrm{Mn}$

\begin{tabular}{lccccc}
\hline \multirow{2}{*}{ Values } & $\mathbf{B}$ & $\mathbf{F e}$ & $\mathbf{C u}$ & $\mathbf{Z n}$ & Mn \\
\cline { 2 - 6 } \multicolumn{1}{c}{} & & $\mathbf{( \mathbf { m g ~ k g } ^ { - 1 } )}$ & & 0.96 \\
Howest & 0.20 & 1.62 & 0.13 & 0.09 & 78.60 \\
Average & 5.24 & 92.81 & 20.60 & 9.15 & 16.71 \\
Kurtosis & 1.22 & 17.70 & 2.40 & 1.46 & 5.23
\end{tabular}


Deliboran \& Savran \& Dursun \& Eralp \& Pekcan \& Turan \& Aydoğdu \& Cllgin \& Ölmez \& Savran \& Nacar Determination of nutritional status of olive (Olea Europaea L.) trees grown in Izmir and Mugla province in terms of boron and the other microelements with soil

\begin{tabular}{lccccc}
\hline Skewness & 1.72 & 1.79 & 3.42 & 2.27 & 2.02 \\
Median & 1.14 & 9.63 & 1.70 & 9.47 & 16.71 \\
Stds & 0.67 & 17.09 & 2.59 & 1.46 & 14.32 \\
Variance & 0.45 & 291.91 & 6.69 & 1.03 & 12.13 \\
DK & 55.47 & 96.54 & 107.96 & 1.32 & 147.25 \\
\hline
\end{tabular}

\subsubsection{EC}

EC values ranged from 0.05 to $1.16 \mathrm{dS} \mathrm{m}^{-1}$ (Table 2). According to Anonymous (1951), 100\% of the soils were included in the saltless class (Table 4). It can be said that the soil of the research area will not be a problem for olive cultivation in terms of salinity. Olive trees are moderately resistant to salt (Ozbek, 1981); (Llamas, 1984). Kasirga (2009) found that the point where Na-origin salinity damage starts for the Gemlik variety is between 4.0 $\mathrm{dS} \mathrm{m} \mathrm{m}^{-1}$ and $8.0 \mathrm{dS} \mathrm{m}^{-1}$. In some studies conducted to determine the nutritional status of olives, all the soils are in the salt-free class in the Western Anatolian Region (Turan et al., 2013), Izmir (Aydogdu, 2011) and Urfa provinces (Soylemez et al., 2017), in the Kapidag peninsula (Saglam et al., 2008), 96\% of olive groves of Armutlu peninsula are in the salt-free class (Uysal et al., 2016). The soluble salt content of olive groves ranged from $0.28 \%$ to $0.40 \%$ and was mostly determined in the less salty class in the Derik region (Doran et al., 2008).

Table 4. The status and distribution of soils in terms of pH, EC, lime and organic matter

\begin{tabular}{|c|c|c|c|c|}
\hline Nutrient & Limits & Evaluation & $\begin{array}{c}\text { Number of sample } \\
\text { (piece) }\end{array}$ & $\begin{array}{c}\text { Distribution } \\
(\%)\end{array}$ \\
\hline \multirow{7}{*}{$\begin{array}{l}\text { Structer } \\
\text { (Anonymous, 1951) }\end{array}$} & & Sandy Loamy & 101 & 39.76 \\
\hline & & Loamy (L) & 38 & 14.96 \\
\hline & & Sandy Clayed Loam (SCL) & 40 & 15.75 \\
\hline & & Clayed (C) & 23 & 9.06 \\
\hline & & Sandy Clayed (SC) & 6 & 2.36 \\
\hline & & Clayey Loamy(CL) & 45 & 17.72 \\
\hline & & Loam Sandy (LS) & 1 & 0.39 \\
\hline \multirow{6}{*}{$\mathrm{pH}$} & $<5.1$ & Strong acid & 1 & 0.39 \\
\hline & $5.1-6.6$ & Mid acid & 57 & 22.44 \\
\hline & $6.6-7.3$ & Neutral & 58 & 22.83 \\
\hline & 7.4-7.9 & Mild alkaline & 128 & 50.39 \\
\hline & $7.9-8.5$ & Alkaline & 10 & 3.94 \\
\hline & $>8.5$ & Strong alkaline & 0 & 0.00 \\
\hline \multirow{5}{*}{$\begin{array}{l}\mathrm{EC} \\
\left(\mathrm{dS} \mathrm{m}^{-1}\right) \\
\text { (Anonymous, 1951) }\end{array}$} & $<2.5$ & Saltless & 254 & 100.00 \\
\hline & $2.6-4.5$ & Brackish & 0 & 0.00 \\
\hline & $4.6-6.9$ & Mesosaline & 0 & 0.00 \\
\hline & $7.0-10$ & High saline & 0 & 0.00 \\
\hline & $>10$ & Extreme saline & 0 & 0.00 \\
\hline
\end{tabular}


JOTAF/ Journal of Tekirdag Agricultural Faculty, 2020, 17(3)

\begin{tabular}{lllcc}
\hline & $<2.5$ & Low & 94 & 37.01 \\
& $2.6-5.1$ & Limy & 41 & 16.14 \\
$\begin{array}{l}\text { Lime } \\
\text { (Evliya, 1964) }\end{array}$ & $5.1-10.1$ & High & 33 & 12.99 \\
& $10.1-20.0$ & Very high & 27 & 10.63 \\
& $>20.0$ & Extreme & 59 & 23.23 \\
\hline \multirow{2}{*}{$\begin{array}{l}\text { OM (\%) } \\
\text { (Thun et al., 1955) }\end{array}$} & $0-2$ & Poor humic & 112 & 44.09 \\
& $2-5$ & Less humic & 141 & 55.51 \\
& $>5$ & Humic & 1 & 0.39 \\
\hline
\end{tabular}

\subsubsection{Lime}

The lime content of the soils ranged between 1.16-74.50\% (Table 2). According to Evliya (1964), 37.01\% of the soils were low, $16.14 \%$ were limy, $12.99 \%$ were high, $10.63 \%$ were very high and $23.23 \%$ were in the extreme class (Table 4). Olive develops very well in calcareous soils (Kacar and Katkat, 1999). It is known that olives tolerate a wide limit in terms of lime, and olive does not lose anything from their productivity (Colakoglu, 1985). However, it shows the best development in 9-19\% so that it contains moderately lime (Hartmann and Lilleland, 1966); (Llamas, 1984); (Mengel and Kirkby, 1987). As a result of the study, 34.40\% of olive groves were found to contain low lime. Olive is actually a drought tolerant plant that can grow in a wide soil reaction, tolerates lime. However, purchasing quality and abundant products requires special conditions to be met (Ozbek, 1981); (Llamas, 1984). For this reason, it is thought that it will be beneficial to make the appropriate amount of liming in the areas with low lime in the region. Approximately $60 \%$ of the area of the research contains high lime (Table 4). For this reason, it is necessary to choose fertilizers with low lime rates and to apply organic fertilizer applications in these areas with high lime content in chemical fertilization. In some studies carried out to determine the nutritional status of olives, it was determined that $32.84 \%$ of the soils are low in the Western Anatolia Region, $29.35 \%$ is limy, $19.90 \%$ is high and $17.91 \%$ is very high lime (Turan et al., 2013); $50 \%$ of the lime is rich in Izmir province (Aydogdu, 2011); the majority of the Kapidag peninsula is low calcareous level (Saglam et al., 2008). In the Derik region, $\mathrm{CaCO}_{3}$ levels vary between $5.03-13.41 \%$ and are in the class of lime-rich soils (Doran et al., 2008) and $47.06 \%$ in the Urfa region are too lime and 32.35\% are too lime (Soylemez et al., 2017 ) and olive groves do not contain lime in the Armutlu peninsula (Uysal et al., 2016).

\subsubsection{Organic matter}

Organic matter contents ranged between 0.86-5.74\% (Table 2). According to Thun et al. (1955), soils of 44.09\% were humus poor, $55.51 \%$ is less humus, and $0.39 \%$ is humic (Table 4). According to the results of the analysis, the organic matter coverage of olive groves is low and proportionally a great majority of soils fall into the less and less class. Olive loves soils with well-ventilated and sufficient moisture. Barnyard manure creates this environment and increases the effectiveness of commercial fertilizers. Because of this reason, it should be applied to the soil adequately and accurately. In addition, an ideal growing environment should be created by combining the soil with organic and inorganic fertilization (Ozbek, 1981); (Cakir and Cavusoglu, 1988). Special attention should be given to the release techniques, the common use of barn manure and green fertilization to improve the soil organic matter level. Organic matter content of soils in the Western Anatolia Region is $26.37 \%$ very low, $58.21 \%$ low, $12.44 \%$ sufficient and 2.98\% high (Turan et al., 2013). It was determined that in Izmir province (Aydogdu, 2011) and Kapidag peninsula (Saglam et al., 2008), all of them are low, in the Gemlik region, 22.7\% are few and very little, 47.7\% are medium and 29.7\% are high and very high (Uysal et al., 2011), 28.9\% are low in Armutlu peninsula, $30.9 \%$ are medium and $40,2 \%$ is determined at a high and very high level (Uysal et al., 2016). While it varied between $1.29-1.98 \%$ in the Derik region (Doran et al., 2008), it was changed between $0.37-2.32 \%$ in the province of Sanliurfa (Soylemez et al., 2017) and both were reported to be insufficient. 
Table 5. The status and distribution of soil in term of microelements

\begin{tabular}{cllcc}
\hline Nutrient & Limits $(\mathbf{m g}$ kg-1) & Evaluation & Number of sample (piece) & Distribution (\%) \\
\hline \multirow{3}{*}{$\mathrm{B}$} & $<0.5$ & Little & 35 & 13.78 \\
& $0.5-2.00$ & Adequate & 194 & 76.38 \\
& $2.00-5.00$ & Much & 24 & 9.45 \\
& $>5.00$ & Too much & 1 & 0.39 \\
\hline \multirow{2}{*}{$\mathrm{Fe}$} & $<2.5$ & Lack & 3 & 1.18 \\
& $2.5-4.5$ & Lack visible & 11 & 4.33 \\
& $>4.5$ & Well & 240 & 94.49 \\
\hline $\mathrm{Cu}$ & $<0.2$ & Insufficient & 3 & 1.18 \\
& $>0.2$ & Sufficient & 251 & 98.82 \\
\hline \multirow{3}{*}{$\mathrm{Zn}$} & $<0.2$ & Too little & 3 & 1.18 \\
& $0.2-0.7$ & Little & 84 & 33.07 \\
& $0.7-2.4$ & Sufficient & 127 & 50.00 \\
& $>2.4$ & Much & 40 & 15.75 \\
\hline \multirow{2}{*}{$\mathrm{Mn}$} & $<0.2$ & Too little & 0 & 0.00 \\
& $0.2-0.7$ & Little & 0 & 0.00 \\
& $0.7-5$ & Sufficient & 21 & 8.27 \\
& $>5$ & Much & 233 & 91.73 \\
\hline
\end{tabular}

\subsubsection{Extractable B}

The extractable B contents of soils ranged between 0.20 to $5.24 \mathrm{mg} \mathrm{kg}^{-1}$ (Table 3). When the extractable B content of soils were evaluated according to Wolf (1971) $13.78 \%$ of the soils were classified as low, $76.38 \%$ adequate, $9.45 \%$ much and $0.39 \%$ too much (Table 5). Total B coverage of the soils is between $20-200 \mathrm{mg} \mathrm{kg}^{-1}$ and the available B fraction is between $0.4-5.0 \mathrm{mg} \mathrm{kg}^{-1}$ (Gupta, 1979); (Deliboran and Savran, 2017). If the amount of extractable boron of the soils is less than $0.5 \mathrm{mg} \mathrm{kg}^{-1}$, the amount of boron suitable for the plant is insufficient, and if it is between $0.5-5.0 \mathrm{mg} \mathrm{kg}$, the amount of boron suitable for the plant is sufficient (Sillanpaa, 1982); (Deliboran and Savran, 2017); (Deliboran et al., 2019a). In this context, it is considered that the area of the research is sufficient in terms of B content. In some studies conducted to determine the nutritional status of olives, boron content of soils is low in the Western Anatolia Region, 32.84\% low, 63.18\% sufficient and 3.98\% high (Turan et al., 2013). In Izmir province, boron contents of soils ranged between 1.47-5.34 mg kg-1 and 1.15-3.87 mg kg-1 in term of variety and the soils are sufficient class (Aydogdu, 2011). In another study, the boron contents of some olive cultivation areas in Izmir province varied between 0.20 and $5.24 \mathrm{mg} \mathrm{kg}^{-1}$ and it was insufficient in approximately $27 \%$ (Deliboran et al., 2019). The B content of olive groves was ranged between $0.37-0.53 \mathrm{mg} \mathrm{kg}$ ${ }^{1}$ in the Derik region and it was inadequate (Doran et al., 2008), while it was insufficient in $100 \%$ in Sanliurfa province (Soylemez et al., 2017).

\subsubsection{Extractable Fe, $\mathrm{Cu}, \mathrm{Zn}$ and $\mathrm{Mn}$}

The extractable Fe contents of soils varied from 1.62 to $92.81 \mathrm{mg} \mathrm{kg}^{-1}$. According to the limit values, $1.18 \%$ of the soils were lack, $4.33 \%$ were lack visible, $94.49 \%$ were well class. The extractable copper contents ranged from 0.13 to $20.60 \mathrm{mg} \mathrm{kg}^{-1}, 1.18 \%$ of soils were insufficient, $98.82 \%$ were sufficient class. Extractable zinc contents ranged from 0.09 to $9.15 \mathrm{mg} \mathrm{kg}^{-1}, 1.18 \%$ of the soils were too little, $33.07 \%$ were little, $50.00 \%$ were sufficient and $15.75 \%$ were much. The extractable manganese contents ranged from 0.96 to $78.60 \mathrm{mg} \mathrm{kg}^{-1}, 8.27 \%$ of the soils were sufficient, $91.73 \%$ were much class (Table 3; 5). When the results are evaluated as a whole, it can be said 
that the soil cultivated in the research area is sufficient in terms of manganese and insufficient in terms of iron, copper and zinc. In a study conducted in the Western Anatolian Region in order to determine the nutritional status of olives, approximately $35 \%$ of the soils in terms of $\mathrm{Fe}$ and $\mathrm{Cu}$ contents; $72 \%$ in terms of $\mathrm{Zn}$ and $11 \%$ in terms of Mn are determined in the low and critical class (Turan et al., 2013). In another study, the iron content of the soil in Izmir province varied between 1.43-3.02 mg kg-1 / 1.15-4.13 $\mathrm{mg} \mathrm{kg}^{-1}$, respectively for Uslu and Domat olive varieties, and all of them were low and critical. It has been reported that the contents of the extractable $\mathrm{Cu}, \mathrm{Zn}$ and Mn varied between 1.11-3.31 mg kg-1 / 0.43-2.55 mg kg-1; 0.86-2.66 mg kg-1 / 0.14-2.76 mg kg-1 $0.76-2.71 \mathrm{mg}$ $\mathrm{kg}^{-1} /$ 0.43-1.87 mg kg-1 respectively, and all three elements were in sufficient class (Aydogdu, 2011). In another study conducted in Izmir province, it has been reported that the extractable $\mathrm{Fe}, \mathrm{Cu}, \mathrm{Zn}$ and Mn contents of olive groves were varied between 2.82-92.81 mg kg-1 $0.41-20.60 \mathrm{mg} \mathrm{kg}^{-1} ; 0.36$ and $9.15 \mathrm{mg} \mathrm{kg}^{-1}$ and 3.47-78.60 mg kg${ }^{1}$, respectively. In term of iron, copper, zinc and manganese, $94 \%, 100 \%, 80 \%$ and $99 \%$ of soils were sufficient class. It has been reported that zinc feeding problems were experienced in the region (Deliboran et al., 2019b). The content of $\mathrm{Fe}, \mathrm{Zn}, \mathrm{Mn}$ and $\mathrm{Cu}$ of olive groves in the Derik region ranged between $6.18-11.3 \mathrm{mg} \mathrm{kg}^{-1}, 3.14-9.27 \mathrm{mg}$ $\mathrm{kg}^{-1} ; 5.32-8.08 \mathrm{mg} \mathrm{kg}^{-1}$ and 1.63-3.48 $\mathrm{mg} \mathrm{kg}^{-1}$, respectively and all of them were identified sufficient class (Doran et al., 2008). In Sanliurfa province, the extractable $\mathrm{Fe}$ and $\mathrm{Cu}$ contents of the soils varied between 1.92-4.13 $\mathrm{mg}$ $\mathrm{kg}^{-1}$ and $0.85-2.30 \mathrm{mg} \mathrm{kg}^{-1}$, respectively and $100 \%$ of them were medium and sufficient, Mn and $\mathrm{Zn}$ contents ranged between $1.80-6.44 \mathrm{mg} \mathrm{kg}^{-1}$ and $0.18-0.55 \mathrm{mg} \mathrm{kg}^{-1}$, respectively, and it were determined that $100 \%$ of soils were too little and little class (Soylemez et al., 2017).

\subsection{Plant analysis results}

The lowest, highest and average element analysis results of leaf samples are given in Table 6 and microelement content and distribution of leaves are given in Table 7.

Table 6. The lowest, higest and average values of total $\mathrm{B}, \mathrm{Fe}, \mathrm{Cu}, \mathrm{Zn}$ and $\mathrm{Mn}$ concentrations of leaf samples

\begin{tabular}{lccccc}
\hline \multirow{2}{*}{ Values } & B & Fe & $\mathbf{C u}$ & $\mathbf{Z n}$ & Mn \\
\cline { 2 - 6 } & & \multicolumn{5}{c}{$\left(\mathbf{m g ~ k g}^{-1}\right)$} \\
Minumum & 8.66 & 23.57 & 3.06 & 3.95 & 8.39 \\
Maximum & 29.33 & 487.68 & 281.81 & 39.14 & 105.13 \\
Average & 16.94 & 120.27 & 18.105 & 14.21 & 27.86 \\
\hline
\end{tabular}

\subsubsection{Total B content of olive leaves}

Total B content of olive leaves varied between 8.66-29.33\% (Table 6) and according to the limit values, 85.04\% of the leaves samples were little, 14.96\% were adequate class (Table 7). According to Reuters and Robinson (1997) B limit values of olive leaves varies between 20-150 $\mathrm{mg} \mathrm{kg}^{-1}$, and according to Jones et al. (1991), it varies between $20-75 \mathrm{mg} \mathrm{kg}^{-1}$. Considering that of $13.78 \%$ of the research area soils has boron feeding problems, $86.22 \%$ of soils contain adequate, much and too much boron, and $85.04 \%$ of the leaves contain little $\mathrm{B}$, it is understood that approximately $86 \%$ of the olive grown areas in Izmir and Mugla province has a serious boron nutritional problems (Table 7). Although there is sufficient boron in almost all soils, the lack of boron in $85.04 \%$ of the leaves indicates that plant does not benefit from the boron in the soil. In the surveys conducted to determine the nutritional status of our country's olive groves, it was determined that the most B, Zn, K, and $\mathrm{N}$ deficiencies were found according to the order of importance (Canozer, 1978); (Dikmelik, 1989); (Genc et al., 1991); (Aksalman et al., 1993); (Tekin et al., 1994). (Doran and Aydın, 1999); (Deliboran et al., 2019); According to Deliboran et al. (2019) in a study conducted in the olive groves of Izmir province, the total boron content of leaves varied between 8.66-24.23\%; although $27.13 \%$ of soils contained a low level of boron, approximately $78 \%$ of leaves were little class, it was understood that there was a serious problem of boron nutritional in Izmir province. It is thought that boron fertilizer applications should be made especially in the regions with boron deficiency. Ozbek (1981) reported that it may be inconvenient to apply to fruit trees with boron deficiency due to the fact that this element is very close to the boundary where the deficiency boundary and the poison effect, so that the desired boron levels in fruits and leaves 
can be achieved by spraying boron from the leaf. He reported that the boron deficiency in boron or boric acid solution could be eliminated by spraying the leaves at a concentration of $0.15-0.24 \%$ in many fruit species. Perica et al. (2001a) investigated the boron movement, mannitol and glucose concentrations in different organs of the Manzanillo olive cultivar in yield age and the effects of change of B application on soluble carbohydrates using labeled B. They reported that after application from leaves of various ages treated with $10 \mathrm{~B}$ application, there was a significant 10B output and a significant 10B increase occurred in neighboring organs that did not apply in inflorescences and fruits. The results proved that B can be carried from leaves of different ages and that B, which is applied from the leaves in olives, is portable in phloem. Soluble carbohydrate analysis found that mannitol and glucose were the dominant sugars in all organs analyzed and that the concentration of mannitol in the leaves was sufficient to calculate the entire B transport.

\subsubsection{Total Fe, $\mathrm{Cu}, \mathrm{Zn}$ and $\mathrm{Mn}$}

The total $\mathrm{Fe}, \mathrm{Cu}, \mathrm{Zn}$ and $\mathrm{Mn}$ contents of olive leaves ranged between $23.57-487.68 \%$; 3.06-281.81\%; $3.95-$ $39.14 \%$; 8.39-105.13\%, respectively (Table 6). Distribution of olive leaves in terms of Fe content were $1.18 \%$ little, $98.82 \%$ adequate class; in terms of $\mathrm{Zn}$ content, $66.54 \%$ little, $33.46 \%$ adequate and much; in terms of $\mathrm{Mn}$ contents, $20.08 \%$ little, $79.92 \%$ adequate and much; in terms of $\mathrm{Cu}$ contents $10.63 \%$ little, $89.37 \%$ adequate and much (Table 7). Considering that $5.51 \%$ of the soil samples were lack and lack visible class (Table 5) and $1.18 \%$ of the leaf samples were little class (Table 7), it is understood that there is a small feeding problem in terms of Fe. In term of $\mathrm{Zn}$ considering that $34.25 \%$ of the soils were too little and little class (Table 5) and $66.54 \%$ of the leaves were little class (Table 7), it is understood that serious $\mathrm{Zn}$ nutrition problems are observed. In terms of $\mathrm{Cu}, 1.18 \%$ of the soil were insufficient (Table 5) and $10.63 \%$ of the leaves were little class (Table 7), in terms of Mn, $100 \%$ of the soil were sufficient (Table 5) and $20 \%$ of the leaves were little, it is understood that there is small $\mathrm{Cu}$ and $\mathrm{Mn}$ nutritional problems in the research province. According to Deliboran et al. (2019), the total $\mathrm{Fe}, \mathrm{Cu}, \mathrm{Zn}$ and Mn contents of the leaves were ranged between $23.57-201.25 \% ; 3.06-169.52 \% ; 3.96-35.73 \% ; 8.39-105.13 \%$, respectively. The researchers said that there were a serious nutritional problems of $\mathrm{Cu}, \mathrm{Mn}$ and $\mathrm{Zn}, 7 \%, 17 \%$ and $64 \%$, respectively and there were not nutritional problems of Fe.

Table 7. Micro elements status and distribution of leaf samples

\begin{tabular}{|c|c|c|c|c|}
\hline Nutrient & Limit (\%) & Evaluation & Number of sample & Distribution (\%) \\
\hline \multirow{3}{*}{$\mathrm{B}$} & $<20$ & Little & 216 & 85.04 \\
\hline & $20-150$ & Adaquate & 38 & 14.96 \\
\hline & $150<$ & Much & 0 & 0.00 \\
\hline \multirow{3}{*}{$\mathrm{Fe}$} & $<30$ & Little & 3 & 1.18 \\
\hline & $30-40$ & Adaquate & 7 & 2.76 \\
\hline & $40<$ & Much & 244 & 96.06 \\
\hline \multirow{3}{*}{$\mathrm{Zn}$} & $<15$ & Little & 169 & 66.54 \\
\hline & $15-30$ & Adaquate & 82 & 32.28 \\
\hline & $30<$ & Much & 3 & 1.18 \\
\hline \multirow{3}{*}{$\mathrm{Mn}$} & $<20$ & Little & 51 & 20.08 \\
\hline & $20-35$ & Adaquate & 156 & 61.42 \\
\hline & $35<$ & Much & 47 & 18.50 \\
\hline \multirow{3}{*}{$\mathrm{Cu}$} & $<4$ & Little & 27 & 10.63 \\
\hline & $4-10$ & Adaquate & 184 & 72.44 \\
\hline & $10<$ & Much & 43 & 16.93 \\
\hline
\end{tabular}




\section{Conclusions}

In this study, the boron nutritional status and some properties of olive cultivated areas in Izmir and Mugla provinces were examined, and the effects of the obtained results on olive farming were evaluated.

According to the results of the research; the vast majority of the research area soils have sandy loamy and clayey loamy structure, the content of organic matter is low. Soils with mild alkaline, neutral and mid acid properties are included in the saltless class. Considering that the olive tree can be grown in a wide soil reaction and shows good development in slightly acidic and slightly alkaline soils, it is seen that the territory of the region is suitable for olive farming in this respect. Since the vast majority of the research area soils contain high lime, particular care should be taken in selecting fertilizers with low lime rates in chemical fertilization. Considering that olives love soils with good air and sufficient moisture, the manure that creates this environment and increases the efficiency of its commercial fertilizers should be applied to the soil adequately and correctly. Also, an ideal growing environment should be created by combining the soil with organic and inorganic fertilization. Special attention should be paid to release techniques, widespread use of barn manure and green manure to improve its level. When the research results are evaluated as a whole in terms of boron, zinc, iron, copper and manganese, it is unterstood that there are serious nutritional problems in terms of $\mathrm{B}$ and $\mathrm{Zn}$. It was also determined that there were nutritional problems, although not very serious in terms of $\mathrm{Fe}, \mathrm{Cu}$ and $\mathrm{Mn}$. Although $86.22 \%$ of the soils contain sufficient boron, the lack of boron in $85 \%$ of the leaves indicates that the plant does not benefit from boron in the soil. In this context, in order to eliminate these nutritional problems in the research area, particular importance should be given to boron, zinc, copper, iron and manganese fertilization.

It is thought that the fruit boron deficiency should be applied precisely from the soil due to the fact that this element is very close to the boundary deficiency and the poison effect of this element. Also it is thought that the desired level of the leaves in fruits trees can be achieved more easily by spraying the boron from the leaf due to the fact that the boron applied from the leaf can easily be carried in the phloem. Considering the results of this study carried out in Izmir and Mugla, it is understood that effective fertilization program, method and time are extremely important. It is thought that quality and high-efficiency production in olive farming can be possible with balanced fertilization, organic fertilizer addition and other technical applications meticulously. 


\section{References} and leaf analyzes

Aksalman, A., Dikmelik, U., Puskulcu, G., Ozgen, N. (1993). Determination of the nutritional status of the olives of Aydin region. Final Report, Olive Research Station, Izmir, Turkey.

Anonymous, (1951). Soil Survey Manuel. Agricultural Research Administration, Department of Agriculture Handbook, No:18, Gount Point Office Washington, USA, 340-377.

Anonymous, (2011). http://www.tuik.gov.tr (accessed date: 29.03.2015)

Anonymous, (2014). http://www.internationaloliveoil.org. (accessed date: 01.05.2015)

Aydogdu, E. (2011). Nutrient content of leaves in Domat and Uslu olive varieties and lnvestigation of their seasonal changes. (Master Thesis) Cukurova University. Institute of Science, Soil Science and Plant Nutrition Department, Adana, Turkey.

Canozer, O. (1978). Nutrient elements status and soil-plant relationship of major olive varieties in the Aegean region. (Specialization Thesis) Olive Research Institute, Bornova, Izmir.

Cakir, M., Cavusoglu, A. (1988). Modern Olive. T.O.K.B. Publication No: 1, Ankara, Turkey.

Colakoglu, H. (1985). Fertilizer and Fertilization. Ege University, Agriculture Faculty Duplication, 17:1. Bornova, Izmir, Turkey.

Deliboran, A., Savran, S. (2017). Boron, its importance in plant physiology and its use in fruit trees. 5th International Participation of Soil and Water Resources Congress. 12-15 September, Kirklareli, Turkey.

Deliboran, A., Savran, K., Dursun, O., Eralp, O., Pekcan, T., Turan, H.S., Aydogdu, E., Cilgin, I., Ata Olmez, H., Savran, S., Ozturk Gungor, F., Yildirim, A., Nacar, A.S. (2019). Determination of nutritional status of olives (olea europaea 1.) grown in mugla province in terms of boron and other elements, leaf and soil relations. IJAAES International Journal of Anatolia Agricultural Engineering ISSN: 2667-7571, (Private No 1): 126-140.

Deliboran, A., Savran, K., Dursun, O., Eralp, O., Pekcan, T,. Turan, H.S., Aydogdu, E., Cilgin, I., Ata Olmez, H., Savran, S., Nacar, A.S. (2019a.). Determination of nutritional status in terms of boron and the other elements of olives (Olea europaea L.) grown in Izmir province. International Semposium on Boron. 17-19 April, Nevsehir, Turkey.

Deliboran, A., Savran, K., Dursun, O., Eralp, O., Pekcan, T,. Turan, H.S., Aydogdu, E., Cilgin, I., Ata Olmez, H., Savran, S., Ozturk Gungor, F., Yildirim, A., Nacar, A.S. (2019b). Determination of Nutritional Status of Olives (Olea europaea L.) Grown in Mugla Province in Terms of Boron and Other Elements, Leaf and Soil Relations. 6. International Participant Soil and Water Congress. $12-14$ November, Menemen, Izmir, Turkey.

Dikmelik, U. (1984). A research on the determination of grain and pruning residues and nitrogen, phosphorus, potassium amounts removed from the soil in nipple olive trees of different ages. Olive Research Institute, Publication No: 31, Bornova, Izmir, Turkey.

Doran, I., Koca, Y.K., Pekkolay, B., Mungan, M. (2008). Determination of the nutritional status of Derik region olive groves. Journal of Akdeniz University Faculty of Agriculture 21(1): 131-138.

Doran, I., Aydın, R. (1999). Determination of the nutritional status of the Icel region olive groves. Anadolu Journal of Aegean Agricultural Research Institute 9 (1): 105-130.

Evliya, H. (1964). Nutrition of Cultivated Plants. Publications of Ankara University, Agriculture Faculty, No: 36, Ankara, Turkey.

Genc, C., Moltay, I., Soyergin, S., Fidan, A.E., Sutcu, A. (1991). Nutritional status of table olives in Marmara region. Bahce, Yalova 20: 1-2.

Gestring, W.D. Soltanpour, P.N. (1981). Evaluation of wet and dry digestion methods for boron determination in plant samples by ICP-AES. Communication in Soil Science and Plant Analysis 12: 743-753.

Gupta, U.C. (1967). A simplified method for determining hot water-soluble boron in soils. Soil Science 103: 424-428.

Gupta, U.C. 1979. Boron nutrition of crops, Adv. Agronomy 31: 273-307.

Hartmann, H.T., Lilleland, O. (1966). Olive Nutrition Temperate to Tropical Fruit Nutrition (Ed: N. F. Childers) Hort. Pub. Rutgers, Chapter $\mathrm{X}$. The State University, New Jersey.

Jones, J.R. Wolf, B., Mills, H.A. (1991). Plant analysis handbook: A practical sampling, preparation, analysis and interpretation Guide. MicroMacro Publishing, Athens, GA. Micro-Macro Publishing.

Kacar, B. (1982). Fertilizers and Fertilization Technique. T.C. Ziraat Bank Cultural Publications, Ankara, Turkey.

Kacar, B., Katkat, A.V. (1999). Fertilizers and Fertilization Technique. Uludag University Strengthening Foundation Release, No. 144, VIPAs, Publication No: 20, Bursa, Turkey.

Kasirga, E. (2009). Investigation of the effects of salinity on Gemlik olives (Olea europaea L.) cultivar. Adnan Menderes University, Institute of Science, ZTO-YL-2009-0003.

Lindsay, W. L. Norwell, W. A. (1978). Development of a DTPA soil test for zinc, 1ron, manganese and copper. Soil Science Society of America Journal 42: 421-428.

Llamas, J. F. (1984). Basis of fertilization in olive cultuvation and the olive trees vegetative cycle and nutritional needs. International Course on Fertilization and Intensitication of Olive Cultivation, UNDP-FAO, Cordoba-Spain.

Mengel, K., Kirkby, A. (1987). Principles of Plant Nutrition. I.P.I. CH. 3048, Worblaufen-Bern. 
Olive Oil Sector Report (2013). ISBN: 978-605-9175-57-9.

Olsen, S. (1972). Micronutrient interactions, micronutrients in agriculture. Soil Science Society of America Ine Madison, Wisconsin USA, 243264.

Ozbek, N. (1981). Fertilization of Fruit Trees. T.O.K.B. 280 p, Ankara, Turkey.

Perica, S, Bellaloui, N., Greve, C., Hu, H., Brown, P.H. (2001a). Boron transport and soluble carbonhydrate concentrations in olive.. Journal of American Society Science 126(3): 291-296.

Reuter, D.J., Robinson, J.B. (1997). Plant Analysis and Interpretation Manual. CSIRO Publishing. ISBN: 643059385, Collingwood, VIC, Australia.

Saglam, M.T., Belliturk, K., Hazinedar, N., Danisman, F. (2008). Nutritional status of Kapıdag peninsula olive groves. Selcuk University, Journal of the Faculty of Agriculture ISSN: 1300-5774, 22(44): 118-123.

Sillanpaa, M. (1982). Micronutrients and the Nutrient Status of Soils. A Global Study. FAO Soils Bulletin No:48, Rome.

Soylemez, S., Oktem, G., Kara, H., Almaca, N.D., Ak, B.E., Sakar, E. (2017). Determination of the nutritional status of the olive groves of Sanliurfa region. Harran Journal of Agricultural and Environmental Sciences 21(1): 1-5.

Tekin, H., Caglar, G., Kuru, C., Akkok, F. (1990). Determination of the nutritional content of pistachios and determination of the most appropriate leaf sample time. 1. Turkey Pistachio Symposium Proceedings. 11-12 September, P. 120-138, Turkey.

Thun, R., Hermann, R., Knickman, E. (1955). Die Untersuchung Von Boden Neuman Verlag, Radelbeul und, p: 48-48, Berlin.

Turan, H.S., Aydogdu, E., Pekcan, T., Colakoglu, H. (2013). Reletionships of olive groves in West Anatolia region of Turkey. Copyright C) Taylor \& Francis Group, LLC ISSN: 0010-3624 print / 1532-2416 online DOI: 10.1080/00103624.2012.734133, Communications in Soil Science and Plant Analysis 44: 80-88.

Turan, H.S., Aydogdu, E., Pekcan, T., Colakoglu, H. (2013). Soil and plant relationships olive groves in West Anatolia region of Turkey. Soil, plant and Food Interactions 473-481.

Tuzuner, A. (1990). Soil and Water Analysis Laboratory Handbook. Ankara.

Uysal, E., Albayrak, B., Soyergin, S. (2011). Determination of nutritional status of olives grown in Gemlik region by soil analysis. 2nd National Soil and Water Resources Congress, 22-25 November Ankara, p: 887-895.

Uysal, E., Albayrak, B., Kayali, F., Karakoc, A. (2016). Determination of the relationship between yield and some soil properties in olive groves grown in Armutlu region. Nevsehir Journal of Science and Technology TARGID, Special Issue 19-31 DOI: 10.17100 / nevbiltek.210955 URL: http: //dx.doi.org/10.17100/nevbiltek.210955.

Wolf, B. (1971). The Determination of boron in soil extracts, plant materials, composts manures, water and nutrient solutions. Communications in. Soil Science and Plant Analysis 2: 363-374. 